\title{
Academic-service partnerships: Seven dimensions of successful collaboration
}

\author{
Lucille Travis $^{1}$, Ann Hart ${ }^{2}$, Sonya R. Hardin ${ }^{1}$, Kathleen Harwell ${ }^{2}$ \\ 1. School of Nursing, University of North Carolina-Charlotte, Charlotte, NC, USA. 2. Nursing Department, CaroMont \\ Health, Gastonia, NC, USA.
}

Correspondence: Lucille Travis. Address: CHHS 412D, University of North Carolina-Charlotte, 9201 University City Blvd Charlotte, NC 28223. Email: Ltravis1@uncc.edu.

Received: December 4, 2011

DOI : $10.5430 /$ jnep.v3n1p1
Accepted: April 20, $2012 \quad$ Published: January 1, 2013

URL: http://dx.doi.org/10.5430/jnep.v3n1p1

\begin{abstract}
Background: Partnerships between an academic institution and a magnet designated facility can enhance the expansion of nursing programs by increasing student enrollment and benefit service organizations through supporting structural empowerment, one of the four model components of Magnet. This article describes an academic-service partnership and the application of 7 dimensions of organizational coordination. Seven dimensions, goals, focus, actors, formalization, resources, focus of power and focus of control, were utilized in the design of the academic-service partnership between University of North Carolina-Charlotte School of Nursing and CaroMont Health System. The academic/service partnerships goals that evolved in the planning of this Academic/Service Partnership were to increase School of Nursing (SON) enrollment to meet workforce needs, attain national standards for NCLEX results, increase preceptorship opportunities for nursing staff by providing preceptor education, utilize university resources to facilitate research in service organization and increase applicant pool for employment of baccalaureate (BSN) registered nurses.
\end{abstract}

Methods: Descriptive longitudinal analysis of data was aggregated over an eight year period. Variables analyzed included student enrollment and National Council Licensure Examination for Registered Nurses (NCLEX-RN) scores of the academic partner as well as recruitment, retention and preceptor work shop participation at the service partner. The satisfaction of preceptors and students in the partnership were obtained. Research initiatives as a result of the partnership were facilitated by a nurse researcher.

Results: The NCLEX-RN average pass rate for all the students who have completed the CaroMont University Student Program (CUSP) has been 97.1\%, while University of North Carolina-Charlotte nursing students had an overall average of 86.25\% during the same time period. Over 30 Registered Nurses (RN) from the hospital and affiliates have participated in preceptor workshops. The data show that outcome of the CaroMont University Student Partner (CUSP) program has increased the number of BSN new graduate nurses hired each year. Additionally, there has been an increase in the clinical research at the health care organization and the University due to the increased collaboration.

Conclusions: The goals should be well delineated, with ownership by both partners. The focus of the partnership should be attended to by each partner, with clear expectations for respective responsibilities. Each of the partners should have specific liaisons (actors) to ensure that decisions are expedited.

\section{Key words}

Partnerships, Clerkships, Attachments, Preceptorship, Academic-service, Clinical 


\section{I ntroduction}

Both the American Association of Colleges of Nursing (AACN) and the American Organization of Nurse Executives (AONE) recommend establishing partnerships with academia to develop best practices, drive realistic curriculums, establish joint faculty to educate nurses, and prepare graduate nurses to meet workforce needs and mitigate shortages ${ }^{[2,3]}$. Partnerships that offer precepted clinical experience for nursing student is often referred to in the international literature as clerkship or clinical attachment ${ }^{[3,4]}$. In the United States, standards for clinical practice are 1 faculty overseeing 10 nursing students on a clinical unit. While some countries may place students in wards with nurses on designated days or as an intensive schedule of working with a specific nurse, western regulations typically require master prepared faculty to oversee clinical.

In the United States partnerships are becoming more important to nurse executives that oversee hospitals. Nurse executives who are leading their organization toward designation or redesignation of Magnet status need external partnerships. This can increase their pool of BSN applicants for employment while providing opportunities for staff nurse empowerment, such as through preceptorship. The Magnet Recognition Program ${ }^{\circledR}$ recognizes healthcare organizations for quality patient care, nursing excellence and innovations in professional nursing practice. This program was developed by the American Nurses Credentialing Center (ANCC) as an initiative to recognize hospitals for nursing quality. The five components evaluated for this designation are: transformational leadership, structural empowerment, exemplary professional practice, innovation and quality ${ }^{[5]}$.

Academic Deans and Directors also need academic-service partnerships to assist in addressing nursing faculty shortages ${ }^{[6,7]}$ and secure additional clinical placements. Academic research can be enhanced through a collaboration of nursing faculty and clinicians to maximize research output and knowledge development ${ }^{[8]}$.

A number of articles have discussed the collaboration between academia and service. For example, the "Traditional Professional Nurse Career Trajectory versus Shared, Career-long Professional Nurse Formation” was discussed by Warner and Burton ${ }^{[9]}$; and Baiardi, Brush and Lapides ${ }^{[10]}$ have described a partnership between a school of nursing and an urban social service agency, and Balakas, Bryant and Jamerson ${ }^{[11]}$ have described an expansion of clinical research through a service/academic partnership. The authors noted that collaboration between clinical and academic programs enhanced success for both entities. Limited data exists in the literature regarding patient care outcomes associated with academic service partnerships over a 15 year period. However, numerous articles seem to be more focused on improving the transition of student to professional nurse. Consequently, an indirect benefit to patients includes new nurses that are familiar with institutional culture and established protocols. Whether this improves patient outcomes, such as, patient satisfaction, length of stay, quality patient indicators (falls, infections, or complications) is unknown and warrants further investigation ${ }^{[12,13]}$.

Over the past 8 years, the AACN has shared information on new partnership initiatives and a variety of collaborations between academia and service ${ }^{[14]}$. Service entities should be selected based upon nurse-patient ratio, facility resources, credentials of potential faculty from the facility, quality of patient care along with a common objective of collaboration. However, literature contains no framework for designing such partnerships and understanding strategies to create the partnerships. This article describes dimensions from Rogers and Whetten's ${ }^{[1]}$ framework to consider in the implementtation of academic service partnership, and provides data on such partnership, including data of the nursing students' successes on the NCLEX-RN, employment and retention, lessons learned and recommendations for instituting similar programs.

According to Warner and Burton ${ }^{[9]}$, "traditional relationships and behaviors of academia and service no longer match the needs of an emerging and reforming health care system. Rather, the relationships required for the evolving health care system involve a cooperative and collaborative partnership". Rogers and Whetten ${ }^{[1]}$ noted that the evolution of coordination between various types of organizations occurs because of the ever changing economic environment in which all types of entities must survive. 


\section{Method and results}

The first step in setting up a partnership is to decide whether a process of cooperation or coordination should be utilized. If an organization and academia choose to use the process of cooperation, then there are no formal rules, each organization has independent goals, there are no vertical or horizontal linkages, relatively few personnel resources are involved and there is little threat to autonomy for each organization. In contrast, the process of corporate coordination results in "a formal agreement between both parties based on joint goals and activities" ${ }^{[1]}$. Coordination often occurs between two actors and is achieved through a control mechanism external to the actors' relationship. In health care, for example, a service facility may allow a school of nursing to come into the facility with a clinical instructor and students to achieve education. There are few rules and few resources exchanged between the facilities. Having a contract requires the actors (administrators) to agree on the specifications of the contract. A medium level of resources is required and there are clearly negotiated rules regarding expectations. The next step along the continuum may be defined as corporate coordination in which an interagency system of administrators agree to a high level of resources driven by mutual interests and shared benefits ${ }^{[1]}$.

\subsection{Dimensions in implementation}

Each of the seven dimensions of Rogers and Whetten ${ }^{[1]}$, goals, focus, actors, formalization, resources, focus of power and focus of control was utilized in the design of the academic-service partnership between University of North Carolina-Charlotte (UNCC) and CaroMont Health System. Table 1 provides information on the application of coordination strategies for academia/service partnerships. This table is discussed in more depth in the discussion of each dimension.

Table 1. Application of Coordination Strategies for Academia/Service Partnerships

\begin{tabular}{|c|c|c|c|}
\hline Dimensions & $\begin{array}{l}\text { Mutual adjustment } \\
\text { “Invisible Hand" } \\
\text { Coordination } \\
\text { Strategy }\end{array}$ & $\begin{array}{l}\text { Alliance } \\
\text { Strategy }\end{array}$ & $\begin{array}{l}\text { Corporate } \\
\text { Strategy }\end{array}$ \\
\hline Goals & $\begin{array}{l}\text { Primary focus on agency } \\
\text { goals } \\
\text { Service: } \\
\text { 1. Provide preceptorship } \\
\text { training to staff nurses } \\
\text { 2. Increase applicant pool } \\
\text { for employment for interns } \\
\text { and registered nurses. } \\
\text { Academia: } \\
\text { Increase SON enrollment to } \\
\text { meet workforce needs. }\end{array}$ & $\begin{array}{l}\text { Agency goals and collective goals } \\
\text { Service: } \\
\text { Increase mentorship opportunity for } \\
\text { nursing staff } \\
\text { Increase empirical outcomes for Magnet } \\
\text { designation } \\
\text { Provide a seamless transition to practice } \\
\text { Improve patient outcomes through } \\
\text { student participation } \\
\text { Academia: } \\
\text { Student learning experiences designed } \\
\text { to build analysis and synthesis of } \\
\text { content. }\end{array}$ & $\begin{array}{l}\text { Shared benefits stressed } \\
\text { Service/Academia } \\
\text { Meet the CCNE requirements of } \\
\text { meeting the need of our community of } \\
\text { interest } \\
\text { Meet the Carnegie criteria for } \\
\text { Community Engagement } \\
\text { Utilize university resources to } \\
\text { facilitate research in service units } \\
\text { Enhance research through university } \\
\text { resources to meet Magnet Designation } \\
\text { requirements. }\end{array}$ \\
\hline Focus & $\begin{array}{l}\text { Service-provides students } \\
\text { with exposure to facility } \\
\text { Academia-students present } \\
\text { in facility }\end{array}$ & $\begin{array}{l}\text { Service-increase pool of applicants } \\
\text { Academia-increase enrollment }\end{array}$ & $\begin{array}{l}\text { A partnership that are formed to meet } \\
\text { regulatory requirements from external } \\
\text { agencies. } \\
\text { Service: Magnet designation; } \\
\text { Baldridge Award; Beacon Award } \\
\text { Academia-CCNE, NLN, Carnegie } \\
\text { Engagement designation; }\end{array}$ \\
\hline Actors & $\begin{array}{l}\text { Clinical Faculty } \\
\text { Staff nurses }\end{array}$ & Administrators or professional & administrators \\
\hline
\end{tabular}

(Table 1 continued on page 4) 
Table 1. (continued)

\begin{tabular}{|c|c|c|c|}
\hline Dimensions & $\begin{array}{l}\text { Mutual adjustment } \\
\text { “Invisible Hand" } \\
\text { Coordination } \\
\text { Strategy }\end{array}$ & $\begin{array}{l}\text { Alliance } \\
\text { Strategy }\end{array}$ & $\begin{array}{l}\text { Corporate } \\
\text { Strategy }\end{array}$ \\
\hline Formalization & Few rules & $\begin{array}{l}\text { Negotiated rules } \\
\text { Such as an agreement or memo of } \\
\text { understanding }\end{array}$ & $\begin{array}{l}\text { High formality } \\
\text { Such as a contract }\end{array}$ \\
\hline Resources & Few resources committed & $\begin{array}{l}\text { Medium level of resource commitment } \\
\text { Service: Adjunct Faculty } \\
\text { Academia: Faculty would work with a } \\
\text { unit on special projects(e.g. evidence } \\
\text { based projects, process improvement \& } \\
\text { research) }\end{array}$ & $\begin{array}{l}\text { Resource commitment high } \\
\text { Academia/Service joint appointments }\end{array}$ \\
\hline $\begin{array}{l}\text { Focus of } \\
\text { power }\end{array}$ & Decentralized power & $\begin{array}{l}\text { May or may not use central } \\
\text { administrative unit } \\
\text { Service/Academia personnel may or } \\
\text { may not be required to demonstrate } \\
\text { outcomes. Use of Service units used on } \\
\text { an informal process }\end{array}$ & $\begin{array}{l}\text { Centralized power } \\
\text { Service/Academia } \\
\text { Stated expectations to be met by both } \\
\text { service and academia personnel } \\
\text { Use of Service units used on a formal } \\
\text { process }\end{array}$ \\
\hline $\begin{array}{l}\text { Focus of } \\
\text { control }\end{array}$ & $\begin{array}{l}\text { Reliance on informal norms } \\
\text { and benefits for agencies }\end{array}$ & $\begin{array}{l}\text { Systems decisions may have to be } \\
\text { ratified } \\
\text { Service/Academia Decisions on which } \\
\text { students to place at facility and which } \\
\text { units will be utilized for clinical } \\
\text { experiences. }\end{array}$ & $\begin{array}{l}\text { Mutual Interests } \\
\text { Service/Academia Personnel that } \\
\text { match the needs of each organization } \\
\text { to ensure empirical outcomes. }\end{array}$ \\
\hline
\end{tabular}

UNCC is an urban educational institution located in North Carolina with an enrollment of 25,000 students. CaroMont Health Care is a 435 bed facility and received Magnet designation in 2007. CaroMont Health is located in Gastonia, North Carolina, approximately 25 miles from the university.

\section{Dimension 1: Goals of an Academic-Service Partnership}

In facilities that hold Magnet designation, a major goal is to foster innovative approaches for cultivating professional practice among staff nurses. Magnet designation, considered the gold standard for nursing excellence in the United States, is conferred by the American Nurses Credentialing Center, an organization dedicated to the recognition of nursing quality. Magnet organizations are exemplary workplaces for nurses with a commitment to the concepts of Structural Empowerment, Transformational Leadership, Professional Practice and New Knowledge, Innovations and Improvements ${ }^{[5]}$.

Structural Empowerment refers to a dynamic environment that includes partnerships to improve the communities served. Professional practice includes models of care that enhance patient outcomes through collaborative practice. Such collaborative practices emerge due to Transformational Leadership. Exemplary professional practice engages nurses in the role of faculty, preceptors, educators and leaders. Nursing education programs are supported by a Magnet facility to develop students in a manner that enhances patient outcomes. New knowledge, innovations, integration of evidence based practice and the discovery of new knowledge positively affect patient outcomes. Structural Empowerment, Transformational Leadership, Professional Practice and New Knowledge, Innovations and Improvements work together to bring about improved patient outcomes in a safe and healthy workplace ${ }^{[5]}$. However, these can be a challenge for organizations; for example, meeting the expectation of a staff that includes more than $40 \%$ of BSN prepared direct care nurses may require innovation. In the fall of 2010, the American Association of Colleges of Nursing reported that 
nationally, almost 50,000 qualified applicants were unable to enroll in nursing programs due to limited classroom and clinical space, a diminishing pool of faculty, and funding cuts in nursing education programs ${ }^{[14]}$.

The UNCC was no different. Each semester there were approximately 150-200 applications for 40 positions in the generic undergraduate program. However, maintaining NCLEX-RN scores was a priority while increasing enrollment.

\section{Dimension 2: Focus}

In the spring of 2002, the Chief Nursing Officer and other nurse leaders from CaroMont Health and the UNCC School of Nursing (SON) began brainstorming ways to increase enrollment in the SON. The engagement of the SON and a practice partner yielded a strong professional relationship. This occurred because each organization was able to identify and support the strategies to achieve their mutual goals ${ }^{[15]}$. The result was the creation of the CaroMont/ University Student Partners [CUSP]. The academic/service partnerships goals that evolved in the planning of this Academic/Service Partnership were increase SON enrollment to meet workforce needs, attain national standards for NCLEX results, increase preceptorship opportunities for nursing staff by providing preceptor education, utilize university resources to facilitate research in service organization and increase applicant pool for employment of BSN registered nurses. Through this cooperative program, CaroMont Health provides both the clinical site and monetarily supports a faculty member to teach 20 students yearly in the 4 semester upper division generic student program. The Magnet hospital facility thus supports 10 junior students and 10 senior students each year. If a student has been admitted to the school of nursing, they are qualified to be in the CUSP program. However, preference has been given to those that reside within close proximity to the health care facility. Figure 1 shows the yearly BSN student enrollment increase since 2004. In addition, CaroMont Health provides students with an exclusive 2-year clinical experience in their facility. Student demographics are no different from the other clinical groups. However the demographics for the CUSP cohort include international, out of the state in which the university is located, and within state. Over the period of five years, seventy-four students were in their early twenties, seven students were in their thirty's and four in their forty's. Out of 85 students, 16 have been second career students, eight males, eight with children, eight married, 15 worked 20 plus hours per week, nine African Americans, three Asian, two Indian, and 71 Caucasian.

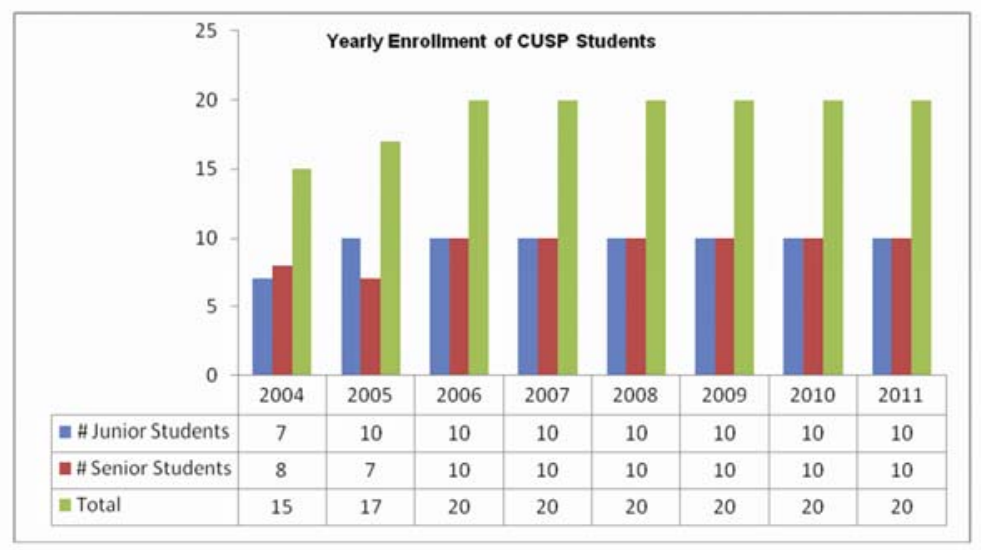

Figure 1. Yearly Enrollment of Students in the CUSP

\section{Dimension 3: Actors}

CaroMont Health hires the program facilitator for the CUSP program. The program facilitator is a full-time, master's prepared "dual role” clinician; paid by CaroMont Health, she also holds an adjunct faculty position at the SON, serves as 
the clinical facilitator for CUSP clinical rotations at CaroMont Health, and oversees projects for nursing administration. In her adjunct faculty role, the facilitator participates in SON functions and maintains strong communication with the SON director and individual course coordinators. These activities ensure that SON standards of instruction and evaluation are maintained, and clinical rotations at CaroMont Health provide comparable clinical experiences for the yearly cohort of 20 CUSP students.

In each clinical rotation, the CUSP teaching team consists of the Clinical Nurse Specialist (CNS), the CUSP facilitator, whose specialty is adult health, the course coordinator at the SON, and CaroMont registered nurses who work on the designated unit. This team approach to clinical teaching differs greatly from the traditional method of assigning up to 10 nursing students to one instructor. When teaching is shared among proficient RNs, students get more expert attention on the unit and they miss fewer clinical learning opportunities due to long waiting times for the clinical instructor. In a study by Myall et al ${ }^{[16]}$, students described individuals who contributed to a good-quality placement as people "who promoted confidence in their students, challenged their practice and offered constructive criticism". Staff nurses are able to assist faculty directly as the CUSP facilitator travels from unit to unit to provide assistance in implementation and evaluation of student nursing care during clinical days.

\section{Dimension 4: Formalization}

The formalization requires that the responsibilities for each CUSP partner are laid out in writing, along with the degree of decision making authority on issues that arise. Steps that should be in place if either party decides to dissolve the partnership should be clear. Lastly, a start date must be agreed upon that allows each partner the time to set into motion changes that will have to be implemented for successful outcomes. All these aspects can be accomplished with a Memo of Understanding or a detailed contract.

\section{Dimension 5: Resources}

The SON conducts the nursing preceptor workshop at the hospital to help clinical nurses improve their mentoring skills with students. Since studies have reported the need for formal preparation as a preceptor Yonge \& Myrick ${ }^{[17]}$, based on recommendations from the $\mathrm{AACN}^{[2]}$, the workshop is designed to help staff gain an understanding of their functions and to assist them in producing professional nurses who are thinking clinicians. Content includes adult learning theories, communication strategies, and development of a student-faculty relationship, instructional techniques for the clinical setting, hands-on care (skills mastery), critical thinking, and provision of feedback. The staff members also learn SON course objectives, which is an advantage for staff, students and faculty. Staff nurses are awarded continuing education credit for completing the workshop. The workshop is a motivator for CaroMont Health staff and it fits well with the Nurse Career Ladder program, since nurses on the Career Ladder seek out opportunities to mentor students and new nursing personnel. Nurses who precept students completing senior practicums are given the opportunity for advancement through meeting career ladder criteria. Preceptors report anecdotally that job satisfaction is increased in the process of participating in the partnership.

In the spirit of partnership, the SON provides a nurse researcher to CaroMont Health on a consultant basis. The nurse researcher, a doctorally prepared nurse, attends monthly Research Council meetings, and provides hospital-wide education on various research topics such as question development, methods, and data analysis. The role also includes collaborating on research projects, reviewing IRB proposals, conducting data analysis, and assisting with developing manuscripts. The nurse researcher enhances success in utilizing evidence based practice and increases research productivity among staff nurses at CaroMont Health. The collaboration has thus helped CaroMont Health strengthen their research endeavors in applying for and receiving American Nurses Credentialing Center Magnet Status. In addition, SON faculty works with nursing staff to develop and implement research projects. Graduate nursing students also find opportunities to collaborate with staff and complete research projects at the hospital. 


\section{Dimension 6: Focus of Power}

In order for decisions to be made about a mutual adjustment, an alliance or a corporate coordination, the actors need to consider whether decisions are to be made centrally or under a decentralized format. A decentralized format is utilized in this partnership which supports Structural Empowerment. One aspect of structural empowerment is that Magnet nurses have "influence to professional groups and advance the nursing profession" ${ }^{[5]}$. This partnership has given the faculty an opportunity to develop structures that encourage educational advancement, the teaching role of Magnet nurses, the transition of new nurses into the work environment, and the support of academic practicum experiences.

Preceptors and the clinical facilitator have decentralized power to critique student performance, identify learning experiences and provide input on evaluations. The clinical facilitator grades student papers and provides the final evaluation for the clinical courses. Through decentralization, preceptors and clinical facilitator are responsible for implementing the course curriculum. The course curriculum consists of the last 2 years of a four year baccalaureate curriculum. All students receive the same curriculum no matter what clinical site is utilized. The course leader [content and clinical] works closely with the CUSP clinical facilitator to ensure that students are progressing successfully in clinical.

\section{Dimension 7: The Focus of Control}

Academic/service partnerships provide a "turning point" in clinical nursing education and a way to reduce the nursing shortage and increase recruitment at facilities. Outcomes should be based upon meeting individual and shared goals for the partnership. Figure 2 (Coordination Strategies for Academia/Service Partnerships) describes coordination strategies for both entities in the academic/service partnership. Academic/service partnership goals are embedded into the appropriate dimensions in the table. Empirical outcomes are measured relative to the goals set forth by the organizations and depend on the type of partnership. Outcomes can be used to show achievement of credentialing agency requirements, such as the Collegiate Commission on Nursing Education (CCNE) and The American Nurses Credentialing Center.

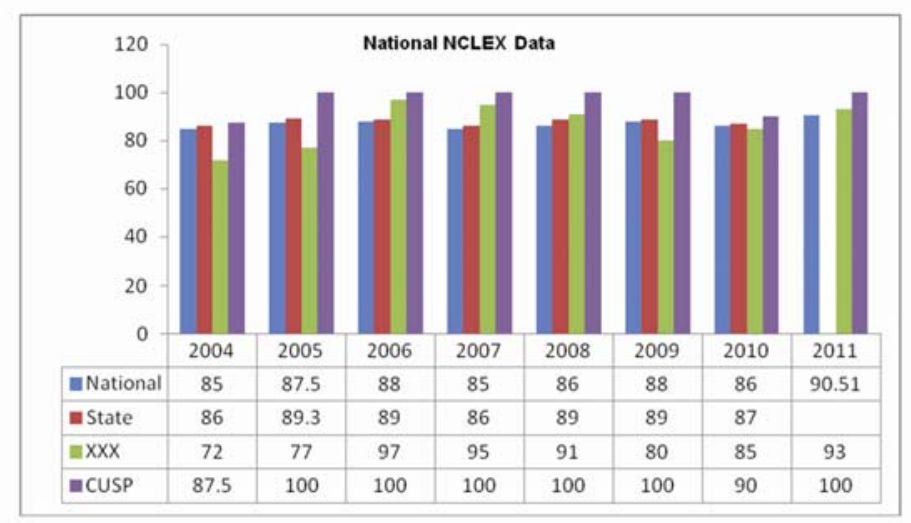

Figure 2. National DATA for NCLEX and CUSP Student Success (move table to below second paragraph under 2.2

In the CUSP program, the mutual interest of academia and service is to increase the number of 4 year BSN nurses, which are needed by Magnet designated faculties and society. The empirical outcomes that were established are the NCLEX-RN scores and the hiring of the CUSP students into clinical positions.

\subsection{Results of academic-service partnership}

The first goal for the CUSP academic-service partnership was to increase SON enrollment to meet workforce needs. Since the beginning of this program, a total of 65 BSN students have successfully completed 2 years of clinical rotations over a period of 6 years at CaroMont Health Care. 
The second goal was to attain national standards for NCLEX results for the CUSP students. The NCLEX average pass rate for all the students who have completed the CUSP program has been 97.1\%, while UNCC students had an overall average of $86.25 \%$ during the same time period. Figure 2 displays National Data for NCLEX, NC State NCLEX, UNCC SON NCLEX and CUSP student success for 2004-2011. CUSP students have scored higher than national, state and UNCC SON NCLEX score averages.

The third goal was to increase preceptorship opportunities for nursing staff by providing preceptor education. Over 30 RNs from the hospital and affiliates have participated in preceptor workshops. A course coordinator and CUSP clinical facilitator conduct the preceptor workshop each year, just prior to the spring semester. Overall, preceptors have been pleased with the workshop. For example, some of the comments have included, "This was awesome and I will be able to apply this knowledge to my work environment," "I will use the information to better understand different co-workers needs and personalities," and "I plan to use the information to be a good resource and experience for my students. I want the experience to be positive and a learning experience." Figure 3 provides yearly data on the number of staff nurses who have participated in the workshop.

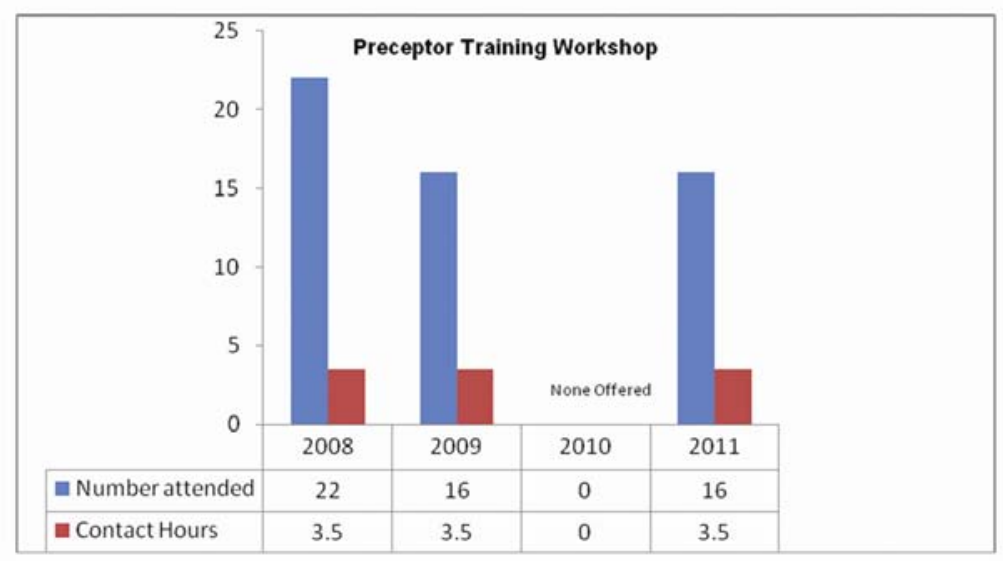

Figure 3. Preceptor Workshop Information

The fourth goal was to increase the applicant pool for employment of BSN registered nurses for CaroMont Health Care. While attempts have been made to enroll students from Gaston County in the CUSP program, some of the students were from other parts of the state or another region of the country. Hence, the number of students who have applied for positions is lower than the total class size. Figure 4 displays the statistics for 2004-2011. The data show that outcome of the CUSP program has increased the number of BSN new graduate nurses hired each year. From 2009 graduating classes, there were 16 BSN prepared new graduate nurses hired by CaroMont Health. Of those 16 new employees, 4 were CUSP nurses, representing 25\% of the BSN-prepared new graduate nurses hired. In 2010, there were 18 BSN-prepared new graduate nurses hired by CaroMont Health. Of the 18, 8 were CUSP nurses, or $44 \%$ of the BSN-prepared new graduate nurses hired. Of the 21 BSN prepared new graduates hired by CaroMont Health in 2011, 8 CUSP students or 38\% of BSN prepared new graduate nurses hired. Figure 5 displays the percentages of CUSP students hired yearly and the total number of BSN new graduates hired.

A survey of nurses in 2005 found that $30 \%$ of respondents left their first nursing position during the first year and $57 \%$ left by their second year ${ }^{[18]}$. Of the students from the CUSP groups who applied and were hired at CaroMont Health after graduation [93\%], 66\% were still employed at CaroMont Health since 2004. The CUSP students have thus had a high retention rate in the organization.

The fifth goal was to utilize university resources to facilitate research in service organizations. The SON provides a nurse researcher to CaroMont Health on a consultant basis. The nurse researcher provides a final review of each study prior to 
IRB submission. Currently CaroMont Health has 22 studies that have been approved by the Council for Research and Evidence Based Practice. Two articles have been published and 14 poster presentations have been selected for regional and national conferences in the past 2.5 years.

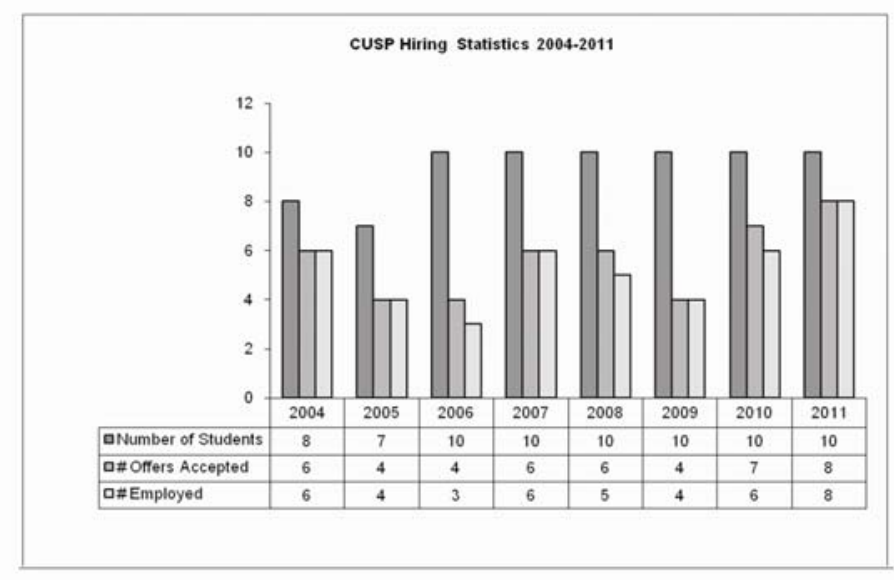

Figure 4. CUSP Hiring Statistics

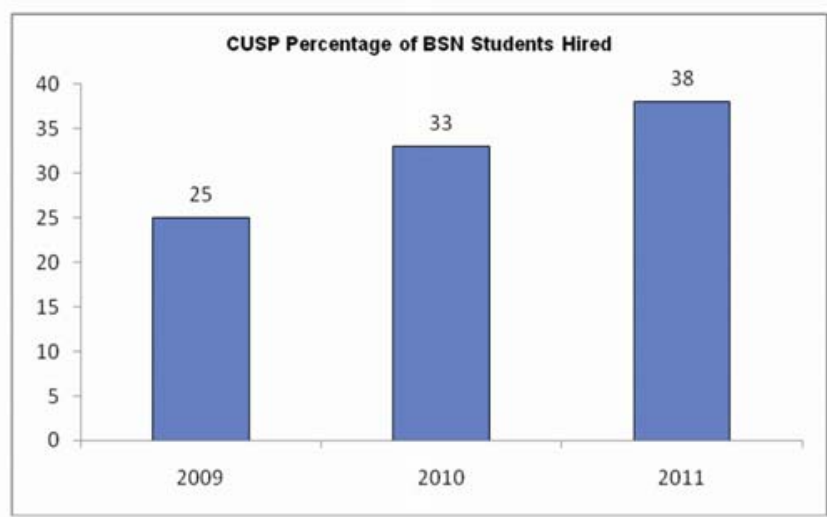

Figure 5. Yearly CUSP Pecentage hired relative to total new Employee hired

\section{Discussion}

The CUSP program met all of the established goals. Enrollment increase is a major result of academic service partnerships. While the CUSP program had one service entity in the partnership supporting a $20 \%$ increase in enrollment, other partnerships have reported enrollment growth that exceeded a 1000 students in a five year period when multiple schools of nursing and healthcare facilities joined together in a community wide partnership ${ }^{[20]}$. The evaluation of NCLEX results for students in academic-service partnerships has not been reported in the literature. The CUSP partnership did have student outcomes where the NCLEX-RN scores for those participating exceeded the overall average of the other students.

Academic service partnerships increase preceptorship opportunities for nursing staff. The literature supports these initiatives as a mechanism to enhance teaching, mentoring, coaching, role modeling professional behavior and developing conflict resolution skills ${ }^{[21-23]}$. In the process of precepting, an increased capacity to recruit and retain students can be 
facilitated by partnerships ${ }^{[22]}$. Such partnerships have been found to decrease nurse vacancy rates ${ }^{[21]}$ and improve staff retention through professional development and nurse satisfaction ${ }^{[24,25]}$.

Increasing the research at health care facilities is an outcome of the CUSP program. Academic-service partnerships expressing a commitment to clinical research will find that the academic partner can help to motivate the involvement of staff nurses in the research process ${ }^{[26]}$ as well as engage students in research studies ${ }^{[27]}$. Design of a focused research agenda that is problem based such as Chronic Illness ${ }^{[8]}$ or cancer ${ }^{[28]}$ has been reported in the literature as a method to leverage the research expertise in a community.

Early literature was focused on the bridge between theory and practice with partnerships. Overtime, a shift occurred in the goals and outcomes of partnerships toward expanding student capacity and addressing faculty shortage.

\section{Conclusion and implications}

The lessons learned in designing an academic-service partnership can be best understood by examining the dimensions: goals, focus, actors, formalization, resources, focus of power, and focus of control (see Figure 1). A corporate strategy was use in the development of the CUSP program and was found to be most effective in meeting the goals of both partners. The goals should be well delineated, with ownership by both partners. The focus of the partnership should be attended to by each partner, with clear expectations for respective responsibilities. Each of the partners should have specific liaisons (actors) to ensure that decisions are expedited. Success of the CUSP program was improved by the weekly communication between the SON and the clinical facilitator. Focused communication provided opportunity for the facilitator to dialogue with the faculty and contribute to curricular and evaluation issues. Students [actors] should be selected, if possible, within the region of the facility. During the formalization, negotiated rules should be clearly articulated. For example, having the facilitator attend didactic classes can enhance the translation of knowledge into practice. Content and expectations for students need to be clear. Resources should be periodically evaluated for cost effectiveness and return on investment. If the focus of power is decentralized, the partners need to be attentive to implementing and evaluating partnership outcomes. There needs to be a feedback loop to ensure that agency benefits are realized. These dimensions can be utilized by international schools of nursing to design partnerships that meet the identified goals of their respective constituencies. Such a framework presents a template for innovative partnerships.

In general, if health care organizations are considering partnering with university schools of nursing, it is useful to review the cost of new graduate recruitment and orientation, as a way to put the costs of a partnership in perspective. Depending on the type of unit, turnover costs vary from $\$ 82,000$ to $\$ 88,000$ per individual. Thus, the cost of a program like CUSP to the health care organization needs to be evaluated in relation to savings in both pre-hire and post hire costs ${ }^{\text {[29] }}$. Also, when evaluating potential benefits and costs of the collaboration, facilities should take into consideration the benefits of and consider the cost of a doctorally prepared nurse researcher which can be comparable to a nurse executive salary. Without accounting for the access to a nurse researcher to facilitate staff research, the facility may miss an important component of the collaboration. There is not an increase cost to the student because they pay the normal tuition regardless of their clinical experience. However, the cost burden is equally distributed between the university and service organization through the interchange of personnel (i.e., nurse researcher and clinical coordinator).

Lastly facilities should consider the cost of marketing their facility to students. Exposure to the facility as a good work environment provides a therapeutic setting for learning. In all nursing programs, the students compare clinical sites and discuss their experiences. Since students complete two years of clinical experience at this facility, they have the opportunity to learn about the strengths of a magnet designated facility.

For a magnet designated facility, a partnership brings a higher level of recognition to the expert clinical teaching of the hospital's nursing staff, which is essential for Magnet designation. The hospital also benefits from recruitment advantages, 
shorter orientation times and positive public relations. In addition, the partnership strengthens research collaboration and can provide the resource of a doctorally prepared nurse researcher to the bedside nursing staff. Structural empowerment is demonstrated through preceptorship of Magnet nurses and the development of student nurses for a seamless transition into a position upon graduation. Benefits to the nursing school include an additional enrollment of students annually through the addition of faculty from the health care facility, improved clinical learning opportunities in a healthy work environment, education for preceptors, clinical input into the nursing curriculum, clinical role modeling for students, and opportunities for shared research. Synchronizing the efforts of such a partnership to maximize achievements can be viewed as innovative, win-win and beneficial for both organizations ${ }^{[2,14,29]}$.

\section{Acknowledgement}

We thank Dr. Joan Stehle Werner for her valuable consultation and assistance in the preparation of this manuscript. We also acknowledge Community Health Partnership, Inc. for funding and the University of Wisconsin-Eau Claire Faculty/Student Research Collaboration Program for past funding and inspiration for this project.

\section{References}

[1] Rogers, D., Whetten, D. Interorganizational Coordination: Theory, Research and Implementation. 1982. Ames, IO: Iowa State University Press.

[2] American Organization of Nurse Executives (AONE). AONE Guiding Principles for the Role of the Nurse Executive in Patient Safety. Chicago, Illinois: AONE. 2007

[3] Wawdhane, S., Saraf, V., Davidson, S. Trewby, P. Clinical attachments: fond farewell or new beginning? A survey of the attitudes and practice of medical consultants and international medical graduates. Postgrad Med J. 2007; 83: 196-199. PMid:17344576 http://dx.doi.org/10.1136/pgmj.2006.050799

[4] Jotkowitz, A., Rosen, S., Warshawsky, S. Karplus, M. Description and evaluation of a clerkship in international health and medicine. Education for Health. 2006; 19(3): 354-362. http://dx.doi.org/10.1080/13576280600938380

[5] ANCC (2012). Magnet Model Components and Sources of Evidence - Second Edition.

[6] American Association of Colleges of Nursing (AACN). White Paper Building Capacity through University Hospital and University School of Nursing partnership [Internet]. 2008. Availabl from: http://www.aacn.nche.edu/Publications/WhitePapers/BuildingCapacity.htm. Accessed November 17, 2008.

[7] Connolly, M.A., Wilson, CJ. Revitalizing Academic-Service partnerships to resolve Nursing Faculty Shortages. AACN Advanced Critical Care. 2008:19(1): 85-97. PMid:18418109 http://dx.doi.org/10.1097/01.AACN.0000310755.23782.96

[8] Dluhy, N., Christopher, K., Gramling, K, Leffers, J., Russell, G, Sethares, K. Embedded, engaged, evolving: A consortium of nurse researchers and clinicians. Nursing Outlook. 2007; 55: 79-84. PMid:17386311 http://dx.doi.org/10.1016/j.outlook.2007.01.001

[9] Warner J.R., Burton, D.A. The policy and politics of emerging academic service partnerships. J Prof Nurs 2009; 25(6): 329-34. PMid:19942198 http://dx.doi.org/10.1016/j.profnurs.2009.10.006

[10] Baiardi, J.M., Brush, B.L., Lapides, S. Common issues, different approaches: strategies for community-academic partnership development. Nurs Inq. 2010; 17(4): 289-96. PMid:21059146 http://dx.doi.org/10.1111/j.1440-1800.2010.00509.x

[11] Balakas, K, Bryant, T, \& Jamerson, P. Collaborative research partnerships in support of nursing excellence. Nurs Clin North Am. 2011; 46(1): 123-8. PMid:21320666 http://dx.doi.org/10.1016/j.cnur.2010.10.006

[12] Tobin, M., Hicke, I. Outcomes of focused service delivery: Developoing an academic-management partnership. Australian and New Zealand Journal of Psychiatry. 1998; 32: 327-336. PMid:9672721 http://dx.doi.org/10.3109/00048679809065524

[13] Cornes, D. Some thoughts on nurse-education/service partnerships. Nurse Education Today. 1998; 18: 655-662. http://dx.doi.org/10.1016/S0260-6917(98)80064-6

[14] American Association of Colleges of Nursing (AACN). New Partnership and Grant-funded Initiatives in Nursing Education Fact Sheet [Internet]. 2011. Available from: http://www.aacn.nche.edu/Media/PartnershipsResource.htm. Accessed August 25, 2011.

[15] American Association of Colleges of Nursing (AACN). Media-Nursing Shortage Fact Sheet [Internet]. 2010. http://aacn.nche.edu/Media/FactSheets/Nursing Shortage.htm. Accessed November 17, 2010.

[16] Graham, R. 10 Questions with Roberta Graham, MS, RN. Syllabus. The Newsletter of the AACN. 2009; 35(2): 4-5.

[17] Mayell, M., Levett-Jones, T., Lathlean, J. Mentorship in contemporary practice: the experiences of nursing students and practice mentors. Journal of Clinical Nursing. 2008; 17(14): 1834-18. PMid:18578757

http://dx.doi.org/10.1111/j.1365-2702.2007.02233.x 
[18] Yonge, O. \& Myrick, F. Preceptorship and the preparatory process for undergraduate nursing students and their preceptors. Journal for Nurses in Staff Development. 2004; 20: 294-297. http://dx.doi.org/10.1097/00124645-200411000-00009

[19] Bowles, C., Candela, L. First Job Experiences of Recent RN Graduates. Student Nurse Update. 2005; 16-19.

[20] Murray, T, Schappe, A, Kreienkamp, D, Loyd, V., Buck, E. A community-wide academic-service partnership to expand faculty and student capacity. Journal of Nursing Education. 2010; 49(5): 295-299. PMid:20143758 http://dx.doi.org/10.3928/01484834-20100115-03

[21] Bratt, M. M. Retaining the next generation of nurses: The Wisconsin nurse residency program provides a continuum of support. The Journal of Continuing Education in Nursing. 2009; 40(9): 416-425. PMid:19754029 http://dx.doi.org/10.3928/00220124-20090824-05

[22] Horns, P, Czaplijski, T, Engelke, M., Marshburn, D., McAuliffe, M \& Baker, S. Leading through collaboration: A regional academic/service partnership that works. Nursing Outlook. 2007; 55: 74-78. PMid:17386310 http://dx.doi.org/10.1016/j.outlook.2007.01.002

[23] Teel, C., MacIntyre, R. Murray, T, \& Rock, K. Common themes in clinical education partnerships. Journal of Nursing Education. 2011; 40(7): 365-372. PMid:21534501 http://dx.doi.org/10.3928/01484834-20110429-01

[24] Clark, R.C., Allison-Jones, l. Investing in human capital: An academic-service partnership to address the nursing shortage. Nursing Education Perspectives. 2011; 32(1):18-21. http://dx.doi.org/10.5480/1536-5026-32.1.18

[25] Murray, T. An academic service partnership to expand capacity: what did we learn? The Journal of Continuing Education in Nursing. 2008; 39(5): 217-224. http://dx.doi.org/10.3928/00220124-20080501-06

[26] Caspers, B, Vlasses, F. Springboard to research: A service and academic partnership. Nurse Leader. 2009; 7(4): 30-34. http://dx.doi.org/10.1016/j.mnl.2009.05.005

[27] Smith, E., Tonges, M. The Carolina nursing experience: A service perspective on an academic-service partnership. Journal of Professional Nursing. 2004; 20(5): 305-309. PMid:15494964 http://dx.doi.org/10.1016/j.profnurs.2004.07.008

[28] Glazer, G, Ponte, P., Stuart-Shor, E., Cooley, M. The power of partnership: addressing cancer health disparities through an academic-service partnership. Nursing Outlook. 2009; 57: 123-131. PMid:19447232 http://dx.doi.org/10.1016/j.outlook.2008.07.007

[29] Jones, C. Revisiting nurse turnover costs. JONA. 2008; 38(1): 11-18. PMid:18157000 http://dx.doi.org/10.1097/01.NNA.0000295636.03216.6f

[30] Brown, D., White, J., Leibbrandt, L. Collaborative partnerships for nursing faculties and health service providers: what can nursing learn from business literature? Journal of Nursing Management. 2006; 14: 170-179. PMid:16600004 http://dx.doi.org/10.1111/j.1365-2934.2006.00598.x 